\title{
Fabrication and Testing of Institutional Stove Using Abura Wood as Fuel
}

\author{
Oji Akuma ${ }^{1}$, Ameh Emma ${ }^{2}$ \\ Chemical Engineering Department, University of Port Harcourt, Port Harcourt, Nigeria, +2348036766966. \\ (email:akuma.oji@uniport.edu.ng). \\ Chemical Engineering Department, University of Port Harcourt, Port Harcourt, Nigeria, \\ (e-mail:Immanuel.ameh.gmail.com).
}

\begin{abstract}
The fabrication and testing of an institutional stove was undertaken in this work. The stove consists of the riser, combustion chamber, skirt, chimney and the stove body. A comparative test with a traditional stove was also carried out employing a water boiling test. Efficiency metrics obtained from the test were used to compare the performance of both stoves. The results obtained show that the time to boil 10 liters of water for the institutional stove was 28 minutes while it took the traditional stove 67 minutes. A high power hot phase test of the institutional stove consumed 1043.728 grams of equivalent dry wood while 1533.306 grams were consumed by the traditional stove. A higher burn rate of $43.489 \mathrm{grams} / \mathrm{min}$ was obtained for the institutional stove while that of the traditional stove is 23.698 grams/min thereby producing more charcoal. The specific fuel consumption value obtained for the institutional stove was 0.113 grams of wood/liter of water while that of the traditional stove was 0.173 grams of wood/liter of water. The traditional stove was calculated to have consumed approximately 35\% more fuel than the institutional stove. The smoke generated during the test was dispersed all around for the traditional stove while that of the institutional stove were conveniently channeled out through a chimney.
\end{abstract}

Keyword: institutional stove, wood, fuel, sustainable, environment.

\section{Introduction}

The use of wood as fuel for domestic and industrial heating has been on for decades. Environmentalist and other stakeholders have also raised concern on the impact of burning wood on human health and the environment. The age long traditional wood burning stoves are encumber with its terribly inefficient, unsustainable, and polluting issues. This has also called for improvement in stove technology to help to reduce the negative effects of the traditional stove by increasing efficiency through advanced combustion and heat conservation techniques.

This calls for synergy to produce a stove hybrid with a twin advantage of efficiency and sustainability as its major selling point. A governmental development agency in India on stove technology and innovative research put the traditional wood burning stove operating thermal efficiency at $6-10 \%$ thermal efficiency. This is rather to low and leaves higher grounds for improvement. The need for efficiency and sustainability is heightened by the fact that, over 2 billion people worldwide are faced with fuel shortages. Forests in developing countries are rapidly decreasing and the ratio of forests-to-people is less than half of what it was in 1960. A 1989 study of 15 developing countries demonstrated a staggering demand for fuel wood of 669,000 hectares needed each year, only about 63,000 hectares are replanted - less than $10 \%$ of the demand (Benjamin, 2005) another study stated that expected wood fuel demand is rising to $213.4 \times 10^{3}$ metric tonnes as against a supply that may decrease to $28.4 \times 10^{2}$ metric tonnes by the year 2030 (Emerhi, 2011; Ijagbemi et al., 2014). This trend of wood use is unsustainable and a widespread increase in stove efficiency could significantly reduce the resource stress and environmental impact.

Furthermore, due to resource availability and the economic situation of the people who use wood burning stoves, the world's poorer half, alternatives to wood and biomass energy are not currently viable or affordable. In fact, many families spend more money on fuel wood than on food, drastically affecting the nutrition levels of the family. Thus, by maximizing the efficiency of wood burning stoves both environmental, economic, and health gains could be achieved. Wood burning stoves also create a great deal of pollution.

Indoor air pollution has been ranked eighth $\left(8^{\text {th }}\right)$ in the health burden worldwide by the World Health Organization. The health burden relates to years loss of healthy life. In developing countries in Africa, which make up $12 \%$ of the world's population, consumes $4 \%$ of global energy. The World Bank called indoor air pollution one of the four largest environmental problems facing the developing world today (Benjamin, 2005). Much of this pollution can be attributed to the use of wood burning stoves for cooking. The fine particulates and carbon monoxide released by wood from incomplete combustion cause acute respiratory ailments, ear and eye problems, breathlessness, chest pains, headaches, dizziness, and more - much of which affects women and 
children. Acute respiratory ailments are the biggest killer of children under five. For some women cooking tortillas for sale in Central America, the inhaled particulate matter is equivalent to smoking 20 packs of cigarettes per day (Benjamin, 2005). This pollution also worsens local air quality in the community and contributes to global warming if the wood use causes deforestation.

The aim of the study is to fabricate an institutional stove. The objectives are to determine the under listed for the fabricated stove and also on a traditional stove: Time to Boil, Temperature Corrected Time to Boil, Burning rate Fuel Consumption, Specific Fuel Consumption and Temperature - Corrected Specific Fuel Consumption. This study will highlight a more effective way of heating or cooking in large quantity while using a minimal amount of fuel (wood and other biomass). The study also shows how a higher heat transfer can be achieved in using this stove. It also shows how we can reduce pollution derived from the burning of fuel directly or indirectly.

\section{Material And Methodology}

These are the various materials and equipment used in the course of conducting this research work. The steel metal sheets, aluminum metal sheets and empty metal drums were obtained from Mile 3 market, Port Harcourt, Nigeria. All welding works were done using a welder from the market. The wood used was obtained from the wood market in Akpajo, Port Harcourt, Nigeria. The water used was from a bore hole water source stored in overhead water tanks.

The institutional stove is made up of different parts perfectly designed in light of the principles that aid the maximum transfer of heat generated by the combustion of biomass fuel into the pot content. The institutional stove is illustrated in Figure 1 while the traditional stove is in Figure 2. The different parts of the stove include the following: A) The combustion chamber, B) The riser, C) The skirt D) The pot area, E) The chimney and F) The stove body

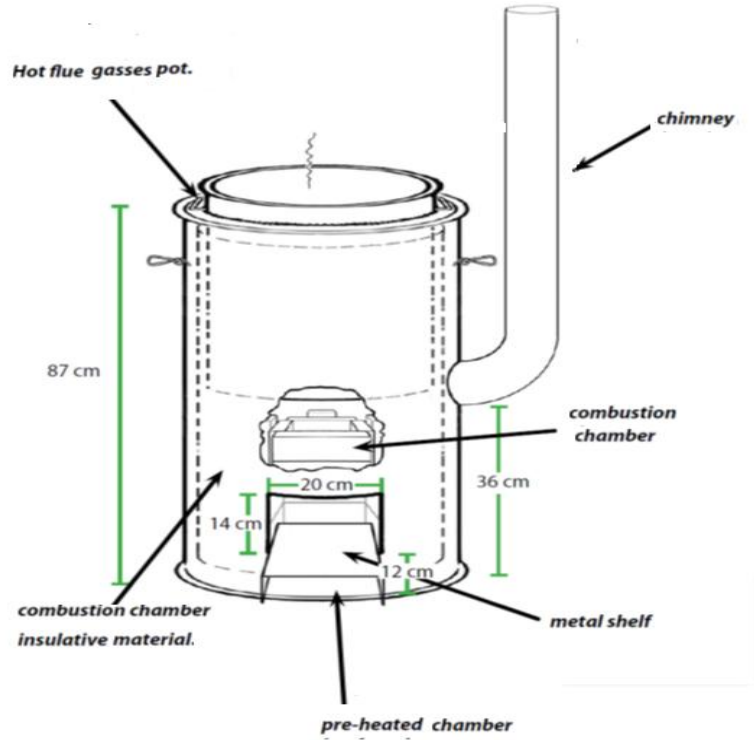

Figure 1: Schematic of an institutional stove with dimensions

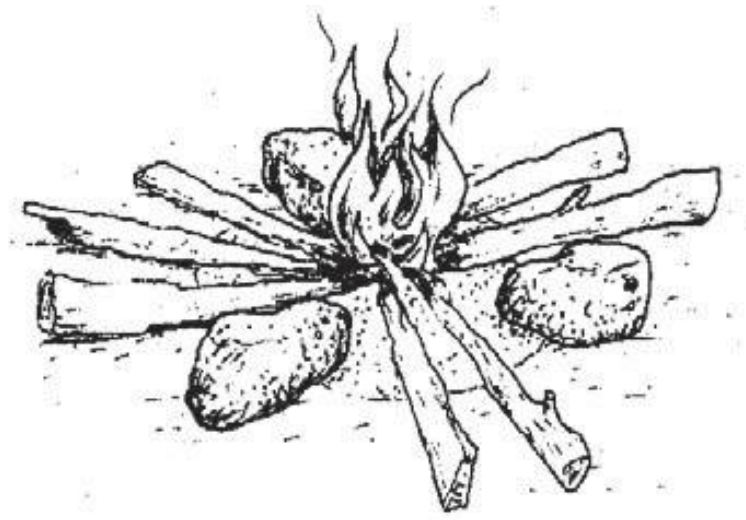

Figure 2: Traditional three stone open fire stove (Mark et al., 2005) 


\section{Test Procedures}

\section{Water boiling test on the Stoves}

This test provides the reliable information about the performance of wood burning stove models. The test consists of two phases that determine the stove's ability to:

- Bring water to a boil from a cold start;

- Bring water to a boil when the stove is hot.

\section{Preparations for the hot and cold water boiling test}

$30 \mathrm{~kg}$ of air-dried Abura wood to ensure that there is enough fuel to complete the tests for the stove. 10 liters of water was put in the testing pot and brought to a rolling boil. An accurate digital thermometer was used to measure the local boiling temperature. The thermometer probe was placed at the center of the testing pot, $5 \mathrm{~cm}$ above the pot bottom. The local boiling point was recorded. The air temperature was record. The weight of pot was recorded without the lid. No lid was used throughout the experiment. The container to be used to collect the charcoal produced after burning of the wood was weighed and recorded. 4 bundles of fuel wood that weighed $4 \mathrm{~kg}$ each to be used for the cold and hot start high power tests were prepared. The approximate dimension of the fuel wood was recorded.

\section{High Power (Cold Start) Phase for the 3 Stone Traditional Stove:}

A 3 stone traditional stove was used. 3 stones were placed $120^{\circ}$ to each other forming a circle. Sticks of the Abura hardwood were from the first $4 \mathrm{~kg}$ bundle and placed between the spaces of the stones with one end meeting at the center of the stones thereby making a 3 stone stove. 10 liters of clean water was filled into a pot. The weight of the pot plus the water was recorded. The pot was then placed on the 3 stone stove. A digital thermometer probe was placed in the center of the pot, $5 \mathrm{~cm}$ from the bottom. The watertemperature was recorded.

The fire was started. Once the fire caught, the timer was started. The pot was brought rapidly to a boil without being excessively wasteful of fuel. When the water in the pot reached the local boiling temperature indicated by the digital thermometer, the following were rapidly done: The time at which the water in the pot reached the local boiling point was recorded. All the wood from the stove were removed and the flames put out. All loose charcoal at the ends of the wood was knocked off into the charcoal tray for weighing. The unburned wood from the stove together with the remaining wood from the pre-weighed bundle were weighed and recorded. The pot with its water was weighed and recorded. All the charcoal from the stove were removed, place with the charcoal that was knocked off the sticks and weighed together. The weight of the charcoal and container were recorded. This completes the high power (cold start) phase for the 3 stone traditional stove. The high power (hot start) test was started immediately.

\section{High Power (Hot Start) Phase for the 3 Stone Traditional stove.}

The pot was refilled with 10 liters of fresh cold water at room temperature. The pot (with water) was weighed and the initial water temperature was taken and recorded. The fire was started using kindling and wood from the second $4 \mathrm{~kg}$ bundle of Abura hardwood (fuel). The time when the fire started was recorded and the pot was brought rapidly to boil without being excessively wasteful of fuel. The time at which the pot reached the local boiling point was recorded. The temperature of the water in the pot was also taken. After reaching the boiling temperature, the following were rapidly done: The time at which the water in the pot reached the local boiling point was recorded. All wood from the stove were removed, and any loose charcoal was knocked off into the charcoal container. The wood removed from the stove was weighed, together with the unused wood from the second bundle. The result was recorded. The pot, with its water was weighed and recorded. All remaining charcoal from the stove was weighed (including charcoal which was knocked off the sticks). The weight of the charcoal plus container was weighed.

\section{High Power (Cold Start) Phase for the Institutional Stove:}

The stove was at room temperature. 10 liters of clean water was filled into the pot. The weight of the pot plus the water was recorded. A digital thermometer probe was placed in the center of the pot, $5 \mathrm{~cm}$ from the bottom. The water temperature was recorded. The fire was started using the wood from the third $4 \mathrm{~kg}$ bundle. Once the fire caught, the timer was started. The pot was brought rapidly to a boil without being excessively wasteful of fuel. When the water in the pot reached the local boiling temperature indicated by the digital thermometer, the following were rapidly done: The time at which the water in the pot reached the local boiling point was recorded. All the wood from the stove were removed and the flames put out. All loose charcoal at the ends of the wood was knocked off into the charcoal tray for weighing. The unburned wood from the stove together with the remaining wood from the pre-weighed bundle were weighed and recorded. The pot with its water was weighed and recorded. All the charcoal from the stove were removed, place with the charcoal that was knocked off the sticks and weighed together. The weight of the charcoal and container were recorded. This completes the high power (cold start) phase for the institutional stove. The stove was not allowed to cool. The high power (hot start) test was started immediately. 


\section{High Power (Hot Start) Phase}

The pot was refilled with 10 liters of fresh cold water at room temperature. The pot (with water) was weighed and the initial water temperature was taken and recorded. The fire was started using kindling and wood from the fourth $4 \mathrm{~kg}$ bundle of Abura hardwood (fuel). The time when the fire started was recorded and the pot was brought rapidly to boil without being excessively wasteful of fuel. The time at which the pot reached the local boiling point was recorded. The temperature of the water in the pot was also taken. After reaching the boiling temperature, the following were rapidly done: The time at which the water in the pot reached the local boiling point was recorded. All wood from the stove were removed, and any loose charcoal was knocked off into the charcoal container. The wood removed from the stove was weighed, together with the unused wood from the second bundle. The result was recorded. The pot, with its water was weighed and recorded. All remaining charcoal from the stove was weighed (including charcoal which was knocked off the sticks). The weight of the charcoal plus container was weighed.

\section{Result and Discussion}

The water boiling test was carried out both for the traditional fire and the institutional stove. The results of the test are giving below.

High Power (Cold Start) Phase for Traditional Stove

The results obtained for the high power cold start and hot start phase are detained in table 1:

Table 1: Cold start and hot start variations for traditional stove

\begin{tabular}{|l|l|l|}
\hline \multicolumn{2}{|c|}{ Parameter } & \multicolumn{2}{c|}{ RESULT } \\
\cline { 2 - 3 } & Cold start & Hot start \\
\hline Initial water Temperature & $29^{\circ} \mathrm{C}$ & $29^{\circ} \mathrm{C}$ \\
\hline Volume of water used & 10 liters & 10 liters \\
\hline Water temperature at boiling point & $101{ }^{\circ} \mathrm{C}$ & $101^{\circ} \mathrm{C}$ \\
\hline Weight of wood bundle before start of test & $4 \mathrm{~kg}$ & $4 \mathrm{~kg}$ \\
\hline Weight of pot + water before test & $12 \mathrm{~kg}$ & $12 \mathrm{~kg}$ \\
\hline Time to boil & $67 \mathrm{mins}$ & $62 \mathrm{mins}$ \\
\hline Weight of wood bundle at end of test & $2 \mathrm{~kg}$ & $2.1 \mathrm{~kg}$ \\
\hline Weight of pot + water after test & $10 \mathrm{~kg}$ & $10.5 \mathrm{~kg}$ \\
\hline Weight of charcoal container + charcoal & $0.635 \mathrm{~kg}$ & $0.62 \mathrm{~kg}$ \\
\hline
\end{tabular}

High Power (Cold Start) Phase for Institutional Stove

The results obtained for the high power cold start and hot start phase for institutional stove are detained in table 2

Table 2: Cold start and hot start variations for Institutional stove

\begin{tabular}{|l|l|l|}
\hline \multicolumn{2}{|c|}{ Parameter } & \multicolumn{1}{c|}{ RESULT } \\
\cline { 2 - 3 } & Cold start & Hot start \\
\hline Initial water Temperature & $29^{\circ} \mathrm{C}$ & $29^{\circ} \mathrm{C}$ \\
\hline Volume of water used & 10 liters & 10 liters \\
\hline Water temperature at boiling point & $101^{\circ} \mathrm{C}$ & $101^{\circ} \mathrm{C}$ \\
\hline Weight of wood bundle before start of test & $3 \mathrm{~kg}$ & $3 \mathrm{~kg}$ \\
\hline Weight of pot + water before test & $12 \mathrm{~kg}$ & $12 \mathrm{~kg}$ \\
\hline Time to boil & $28 \mathrm{mins}$ & $24 \mathrm{mins}$ \\
\hline Weight of wood bundle at end of test & $1.9 \mathrm{~kg}$ & $2 \mathrm{~kg}$ \\
\hline Weight of pot + water after test & $11.2 \mathrm{~kg}$ & $11.4 \mathrm{~kg}$ \\
\hline Weight of charcoal container + charcoal & $0.563 \mathrm{~kg}$ & $0.557 \mathrm{~kg}$ \\
\hline
\end{tabular}

The performance of the two stoves is presented in table 3 .

Table 3: Performance variation for traditional and institutional stove

\begin{tabular}{|c|c|c|c|c|}
\hline \multirow[t]{2}{*}{ Parameter } & \multicolumn{2}{|c|}{ Traditional stove } & \multicolumn{2}{|c|}{ Institutional stove } \\
\hline & Cold Start & Hot start & Cold Start & HOT START \\
\hline Air Temperature $\left({ }^{\circ} \mathrm{C}\right)$ & 28 & 28 & 28 & 28 \\
\hline Initial water Temperature $\left({ }^{\circ} \mathrm{C}\right)$ & 29 & 29 & 29 & 29 \\
\hline Volume of water (liters) & 10 & 10 & 10 & 10 \\
\hline Water temperature at boiling point $\left({ }^{\circ} \mathrm{C}\right)$ & 101 & 101 & 101 & 101 \\
\hline Weight of wood consumed $(\mathrm{Kg})$ & 2 & 1.8 & 1.1 & 1 \\
\hline Weight of charcoal $(\mathrm{Kg})$ & 0.135 & 0.120 & 0.063 & 0.057 \\
\hline Time to boil (Mins) & 67 & 62 & 28 & 24 \\
\hline Mass of water vapourised (kg) & 2 & 1.5 & 0.8 & 0.6 \\
\hline
\end{tabular}

Fuel consumption comparison by the weight of wood consumed and charcoal produce.

The traditional stove consumed more wood $(2 \mathrm{~kg})$ than the institutional stove $(1.1 \mathrm{~kg})$ in the high power cold state phase of the test carried out. Also the weight of charcoal produced by the traditional stove $(0.135 \mathrm{~kg})$ is quite 
higher than that produced by the institutional stove $(0.063 \mathrm{~kg})$ as shown in table 4 . the traditional stove consumed more wood $(1.8 \mathrm{~kg})$ than the institutional stove $(1.0 \mathrm{~kg})$ in the high power cold state phase of the test carried out. Also the weight of charcoal produced by the traditional stove $(0.120 \mathrm{~kg})$ is quite higher than that produced by the institutional stove $(0.057 \mathrm{~kg})$.

Water boiling test

As shown in table 3, the traditional stove took more time to boil (67 minutes) 10 liters of water than the institutional stove (28 minutes) in the high power cold state phase of the test carried out. Also in the high power cold state phase of the test carried out, the traditional stove took more time to boil (62 minutes) 10 liters of water than the institutional stove (24 minutes).

\section{EFFECIENCY METRICS}

The efficiency metrics to be derived for the stoves for effective comparison:

\section{Time to Boil}

Table 4: water boiling test variation

\begin{tabular}{|l|c|c|c|c|}
\hline \multirow{2}{*}{ Parameter } & \multicolumn{2}{|c|}{ Traditional stove } & \multicolumn{2}{c|}{ Institutional stove } \\
\cline { 2 - 5 } & Cold Start & Hot start & Cold Start & Hot start \\
\hline Initial water Temperature $\left({ }^{\circ} \mathrm{C}\right)$ & 29 & 29 & 29 & 29 \\
\hline Water temperature at boiling point $\left({ }^{\circ} \mathrm{C}\right)$ & 101 & 101 & 101 & 101 \\
\hline Time to boil (mins) & 67 & 62 & 28 & 24 \\
\hline
\end{tabular}

From the table 4, for water boiling test result, it can be deduced that the time to boil for the institutional stove is lower to that of the traditional when compared. For the cold start phase, the institutional stove time to boil was 28 minutes and that of the traditional stove was 67 minutes. For the hot start phase, the institutional stove time to boil was 24 minutes and that of the traditional stove was 62 minutes.

\section{Temperature Corrected Time to Boil}

Table 5: Corrected time to boil variation

\begin{tabular}{|c|c|c|c|c|}
\hline \multirow[t]{2}{*}{ Parameter } & \multicolumn{2}{|c|}{ Traditional stove } & \multicolumn{2}{|c|}{ Institutional stove } \\
\hline & Cold Start & Hot start & Cold Start & Hot start \\
\hline Initial water Temperature $\left({ }^{\circ} \mathrm{C}\right)$ & 29 & 29 & 29 & 29 \\
\hline Water temperature at boiling point $\left({ }^{\circ} \mathrm{C}\right)$ & 101 & 101 & 101 & 101 \\
\hline Time to boil (mins) & 67 & 62 & 28 & 24 \\
\hline Corrected Time to Boil (mins) & 69.79 & 64.58 & 29.17 & 25 \\
\hline
\end{tabular}

This is similar to time to boil but the results are adjusted to a standard $75^{\circ} \mathrm{C}$ temperature change (from $29^{\circ} \mathrm{C}$ to $101^{\circ} \mathrm{C}$ ). This adjustment standardizes the results and facilitates a comparison between tests that may have used water with higher or lower initial temperatures. It was observed that the temperature corrected time to boil for the institutional stove is lower than that obtained for the traditional stove both in the cold start and hot start phase.

\section{Equivalent Dry Wood Consumed}

The equivalent dry fuel consumed adjusts the amount of dry fuel that was burned in order to account for two factors: (1) the energy that was needed to remove the moisture in the fuel and (2) the amount of char remaining unburned. (Alliance Patners, 2014). From the result the institutional stove has a lower equivalent dry wood consumption value (1043.728grams of wood in the hot phase) than that of the traditional stove (1469.272grams of wood in the hot phase). This is approximately $41 \%$ decrease in equivalent dry wood consumed by the institutional stove.

Table 6: Equivalent Dry wood consumed

\begin{tabular}{|l|c|c|c|c|}
\hline \multirow{2}{*}{ Parameter } & \multicolumn{2}{c|}{ Traditional stove } & \multicolumn{2}{c|}{ Institutional stove } \\
\cline { 2 - 5 } & Cold Start & Hot start & Cold Start & Hot start \\
\hline Weight of wood consumed (kg) & 2 & 1.8 & 1.1 & 1 \\
\hline Weight of charcoal produced (kg) & 0.135 & 0.12 & 0.063 & 0.057 \\
\hline Time to boil (mins) & 67 & 62 & 28 & 24 \\
\hline Equivalent Dry Wood Consumed (g) & 1533.306 & 1469.272 & 1208.542 & 1043.728 \\
\hline
\end{tabular}

\section{Burning Rate}

Table 7: Burning rate variation

\begin{tabular}{|c|c|c|c|c|}
\hline Parameter & \multicolumn{2}{|c|}{ Traditional stove } & \multicolumn{2}{c|}{ Institutional stove } \\
\cline { 2 - 5 } & Cold Start & Hot start & Cold Start & Hot start \\
\hline Weight of wood consumed $(\mathrm{kg})$ & 2 & 1.8 & 1.1 & 1 \\
\hline Weight of charcoal produced $(\mathrm{kg})$ & 0.135 & 0.12 & 0.063 & 0.057 \\
\hline Equivalent Dry Wood Consumed $(\mathrm{g})$ & 1533.306 & 1469.272 & 1208.542 & 1043.728 \\
\hline Burning Rate $(\mathrm{g} / \mathrm{min})$ & 22.885 & 23.698 & 43.162 & 43.489 \\
\hline
\end{tabular}


The burning rate measures the average grams of wood burned per minute during the test. This measure indicates how rapidly the stove consumes fuel efficiently (Alliance, 2014). It can be seen from the table above that a better burning rate was achieved by the institutional stove when compared in both the cold and hot phase test carried out to with the traditional stove.

\section{Specific Fuel Consumption:}

The specific Fuel consumption in the high power phases (both for the cold and hot phases) indicates the mass of fuel required to complete the task of boiling one liter (or kilogram) (including the evaporation of some water). From our calculated values obtained above, the institutional stove specific fuel consumption has a lower value of 0.113 grams of wood/liter of water (in the hot start) and that of the traditional stove of 0.173 grams of wood/liter of water. This is $34.68 \%$ higher than that of the institutional stove. Therefore the traditional stove consumes approximately $35 \%$ more fuel than the institutional stove. Since the specific fuel consumption is lower for institutional stove, lesser pollutants are also released to the environment, making this stove more environmentally friendly than the traditional stove.

Table 8: Specific Fuel consumption variation

\begin{tabular}{|l|c|c|c|c|}
\hline \multirow{2}{*}{ Parameter } & \multicolumn{2}{c|}{ Traditional stove } & \multicolumn{2}{c|}{ Institutional stove } \\
\cline { 2 - 5 } & Cold Start & Hot start & Cold Start & Hot start \\
\hline Equivalent Dry Wood Consumed $(\mathrm{g})$ & 1533.306 & 1469.272 & 1208.542 & 1043.728 \\
\hline Mass of water simmered $(\mathrm{kg})$ & 8000 & 8500 & 9000 & 9200 \\
\hline Specific Fuel Consumption $\left(\mathrm{g} /\right.$ liter $\left.\mathrm{H}_{2} \mathrm{O}\right)$ & 0.192 & 0.173 & 0.134 & 0.113 \\
\hline
\end{tabular}

\section{Temperature - Corrected Specific Fuel Consumption:}

Table 9: Temperature -Specific Fuel Consumption variation

\begin{tabular}{|c|c|c|c|c|}
\hline \multirow[t]{2}{*}{ Parameter } & \multicolumn{2}{|c|}{ Traditional stove } & \multicolumn{2}{|c|}{ Institutional stove } \\
\hline & Cold Start & Hot start & Cold Start & Hot start \\
\hline Specific Fuel Consumption (g/liter H2O) & 0.192 & 0.173 & 0.134 & 0.113 \\
\hline Initial water Temperature & 29 & 29 & 29 & 29 \\
\hline Water temperature at boiling point & 101 & 101 & 101 & 101 \\
\hline Temperature -Specific Fuel Consumption (g/liter H2O) & 0.2 & 0.18 & 0.14 & 0.118 \\
\hline
\end{tabular}

The Temperature corrected - specific Fuel consumption in the high power phases (both for the cold and hot phases) indicates the mass of fuel required to complete the task of boiling one liter (or kilogram) (including the evaporation of some water) adjusted to 75 degrees of the boiling temperature range. From our calculated values obtained above, the institutional stove specific fuel consumption has a lower value of 0.118 grams of wood/liter of water (in the hot start) and that of the traditional stove of 0.180 grams of wood/liter of water. This is $34.44 \%$ higher than that of the institutional stove. Therefore the traditional stove consumes approximately $34 \%$ more fuel than the institutional stove.

\section{Conclusion}

The fabrication of an institutional stove was carried out. A water boiling test was done to determine some selected efficiency metrics to the fabricated stove. The same test was also carried out on a traditional stove (three stone stove). It was observed that the institutional stove outperformed the traditional stove not only in efficiency but also by implication; it is more environmentally friendly as lesser pollutant was generated since less fuel was consumed in comparison with the traditional stove. A shorter time to boil was observed when using the traditional stove to bring a given amount of water to boil than what was obtained for the traditional stove. A better burning rate was also obtained thereby producing less charcoal thereby conserving more fuel. For the traditional stove, a higher equivalent dry wood was consumed during its operation that that obtained in the institutional stove in boiling the same initial amount of water. Also, a lower specific fuel consumption was obtained for the institutional stove implying that lesser fuel would be required to bring a given amount of water (or food) to boil.

\section{References}

[1]. Alliance Partners, 2014. Water Boiling Test. Retrieved on August 22, 2016 from from: http://cleancookstoves.org/technology-andfuels/testing/protocols.html

[2]. Benjamin W., 2005. An Improved Wood Cookstove: Harnessing Fan Driven Forced Draft for Cleaner Combustion. Department of Mechanical Engineering, Trinity College. Retrieved on August 17, 2016 from http://aprovecho.org/?paybox_id=71

[3]. Emerhi E. A., 2011, Physical and combustion properties of briquettes produced from sawdust of three hardwood species and different organic binders, Advance in applied science research, 2 (6) : 236-246.

[4]. Ijagbemi C. O., Adepo S. O., and Ademola K. S., 2014, Evaluation of combustion characteristic of charcoal from diffent tropical wood species. IOSR Journal of engineering, Vol. 6 Pg 50-57.

[5]. Larry W., 2006. The Institutional Rocket Stove. Retrieved on August 17, 2016 from http://aprovecho.org/?paybox_id=88

[6]. Mark B., Dean S., Peter S., Geoff Hoff., Damon O., Rob B. \& Ken G., 2005. Design Principles for Wood Burning Cook Stoves. Retrieved on August 22, 2016 from http://www.rocketstove.org/images/stories/design-principles-for-wood-burning-cook-stoves.pdf 